IJLR: International Journal of Law Recontruction

Volume 5, Number 2, September 2021

DOI : http://dx.doi.org/10.26532/ijlr.v5i2.16291

\title{
THE SEVERAL UNLAWFUL ACT AFTER NUPTIAL AGREEMENT IN INDONESIA
}

\author{
Heriyanti \\ Universitas Prima Indonesia Medan \\ heriyanti@unprimdn.ac.id \\ Elvira Fitriyani Pakpahan \\ Universitas Prima Indonesia Medan \\ elvirapakpahan@unprimdn.ac.id \\ Diana \\ Universitas Prima Indonesia Medan \\ dianamei275@gmail.com
}

\begin{abstract}
The rule of Constitutional Court has eased on the essential interpretation inherent in the prevailing prenuptial agreement. The prenuptial agreement is understood no longer as the one drawn up prior to the marital process but thereafter as well, as long as it is not against the norms of religion, public order, morals, and third parties. Essentially, it is in accordance Act on Marriage and seemingly more comprehensive than the interpretation of marital agreement of inherence at civil law. The approach method used is a normative juridical approach, the research results obtained state that the implication that the marital agreement can be drawn up either after or before the nuptial execution. The nuptial agreement is compulsory to be legalized on the notarial deed before the execution. The nuptial agreement before or at the moment of marital execution process under the terms that it does no harm to the third part
\end{abstract}

Keywords: Agreement; Prenuptial; Unlawful.

\section{A. INTRODUCTION}

Marriage agreements in general cannot be separated from the legal concept of joint property at the time of marriage. The marriage agreement is also called a pre-nuptial agreement as a deviation in accordance with the legal concept of joint property. According to the provisions of the marriage law, property acquired during marriage becomes joint property. In formal juridical terms, it can be understood the meaning of joint property is property of husband and wife obtained during marriage. ${ }^{1} \mathrm{~A}$ marriage agreement is an agreement made by a prospective husband and wife before and when the marriage is carried out which aims to regulate the

1 Evi Djuniarti, Hukum Harta Bersama Ditinjau Dari Perspektif Undang-Undang Perkawinan dan KUHPerdata, Jurnal Penelitian Hukum De Jure, Vol. 17 No. 4 December 2017, page.445-461 
consequences that will arise from the marriage on the assets of the husband and wife. ${ }^{2}$

In Islamic law, marriage, also known as marriage, is a contract (agreement) that contains legal provisions for the permissibility of having sexual relations using certain pronunciations. ${ }^{3}$ This understanding only refers to sexual relations which were originally not allowed because the existence of a contract in a marriage made the sexual relationship permissible. In his book Rahmat Hakim there is a statement that "Marriage is a contract that causes the ability to get along between a man and a woman and help each other between the two and determine the limits of rights and obligations between them". ${ }^{4}$ Marriage does not only result in the permissibility of sexual relations for men and women, but there is an element of mutual help between the two so that it has implications for the rights and obligations of each husband and wife.

In making a marriage agreement, it includes 3 (three) types of agreed assets, namely: a. property union; b. Husband's personal property c. Wife's personal property. ${ }^{5}$ The contents of the agreement are based on the agreement of both parties between husband and wife, but must not conflict with applicable regulations, the parties have freedom regarding the contents of the marriage agreement to be made without being able to override the rights and obligations of husband and wife. ${ }^{6}$

At or before the marriage, husband and wife with mutual agreement can make a written agreement which is authorized by the marriage registrar, provided that the contents of the agreement also apply to third parties as long as the third party is related to the contents of the agreement. This is in accordance with the mandate of Article 29 (1) of Act No. 1 of 1974 concerning Marriage. Furthermore, the agreement is given approval by the marriage registrar, where the contents of the agreement also apply to third parties related to the agreement, which is often said to be a pre-nuptial agreement, meaning that the agreement was made before the marriage took place.

The basic principle of a marriage agreement made before marriage is that there are fundamental differences after the issuance of the Constitutional Court's decision no. 69/PUU-XIII/2015 dated 27 October 2016. The Constitutional Court allows some rules regarding marriage agreements in accordance with Act No.1 of 1974, mandating that marriage agreements may be made before or during the marriage. Marriage

2 Titik Triwulan, Hukum Perdata Dalam Sistem Hukum Nasional, Kencana Prenada Media Grup, Jakarta, 2011, page.34

3 Abdul Rahman Ghozali, Fiqh Munakahat, Kencana Prenadamedia Group, Jakarta, 2014, page. 8

4 Rahmat Hakim, Hukum Perkawinan Islam (untuk IAIN, STAIN, PTAIS), CV Pustaka Setia, Bandung, 2000, page.13.

5 Ali Afandi, Hukum Waris, Hukum Keluarga, Hukum Pembuktian,: Bina Aksara, Jakarta, 1986, page. 174

6 Sonny Dewi Judiasih, Bambang Daru Nugroho, Deviana Yuanitasari, Revi Inayatillah, Perjanjian Kawin Setelah Berlakunya Putusan Mahkamah Kostitusi No.69/PUU-III/2015, Cakra, Bandung, 2018, page.3 
agreements made before marriage at this time are no longer taboo for the people of Indonesia, especially notaries are used to making the marriage agreement deed, this is done solely to protect the property obtained by each party, so that In the future, the legal consequences of a legal act can be accounted for by each party who did it so that it does not involve the assets obtained by each party. ${ }^{7}$

The Marriage Agreement after the previous marriage is not known or regulated in Act No. 1 of 1974 concerning Marriage, but after the Constitutional Court's Decision on Article 29 paragraphs (1), (3), and (4) which according to the Constitutional Court must be interpreted, it can also be carried out on when the marriage bond has taken place if there is mutual agreement between husband and wife, this will become a legal problem when the Constitutional Court's decision is faced with the provisions of Article 186 of the Civil Code which regulates the process of making a Marriage Agreement Deed after marriage (separation of assets) which must obtain a court order first. ${ }^{8}$

Thus, based on the decision of the Constitutional Court, the application of an extensive or broad interpretation that affects the legal norms in Article 29 paragraphs (1) and (3) and (4) with the implementation and implementation of the marriage agreement at this time is not limited or occurs before the marriage occurs. , but can also be carried out when the marriage occurs on the basis of an agreement between husband and wife together. In other words, the Constitutional Court's decision is to advance the progressive application of the law which is intended to be able to cover the legal vacuum for the development of new phenomena that currently exist in the community. This is of course to deal with the possibility of risks that cause a balance in the legal arrangement regarding joint property in marriage.

Constitutional Court Decision No. 69/PUU-XIII/2015 raises several views of the pros and cons related to the impact of the decision. Most of the parties regretted the issuance of the Constitutional Court's decision, because it could not be separated from the good faith of the parties in making it. The dynamics of life is a cycle that will be passed while navigating the household ark. These dynamics, among others, raise the need to make a marriage agreement, not only a marriage agreement made before or during the marriage, but also a marriage agreement during the marriage bond. In many marriage agreements made after being made with the aim of finding legal loopholes to include the interests of individuals who intentionally or due to negligence have caused harm to the other party. ${ }^{9}$ In making a marriage agreement that occurs after the marriage causes an unlawful act (onrechtmatige daad) it can cause harm to other third parties.

7 Eva Dwinopianti Implikasi dan Akibat Hukum Putusan Mahkamah Konstitusi Nomor 69/PuuXiii/2015 terhadap Pembuatan Akta Perjanjian Perkawinan Setelah Kawin yang Dibuat di Hadapan Notaris, Lex Renaissance, Vol. 2 No. 1 January 2017, page.16-34

8 Ibid.

9 I Nyoman Putu Budiartha, Dilema Penegakan Hukum Putusan MK No.69/PUU-XII/2015 (Persoalan Perkawinan Campuran Tanpa Perjanjian Kawin), Jurnal Notariil, Vol. 1, No. 2, May 2017, page.1-12 


\section{B. RESEARCH METHODS}

The approach method used in this study uses a normative juridical approach. Research with normative juridical methods is legal research carried out by examining library materials or secondary data. ${ }^{10}$ Descriptive research aims to accurately measure certain social phenomena and provide an overview of the symptoms that are the main issues discussed, while analytical research aims to analyze problems that arise in research. ${ }^{11}$

\section{RESULTS AND DISCUSSION}

\section{Unlawful Act Post Nuptial Agreement in Indonesia}

The marriage agreement is called huwelijks voorwaarden in English, while the marriage agreement is called the prenuptial agreement. Huwelijk with the meaning of marriage between a man and a woman, on the other hand voorwaard with the meaning of conditions. ${ }^{12}$ Thus, a marriage agreement is an agreement that occurs between a woman and a man as a life partner at the time of marriage or before the marriage takes place in which both parties promise to comply with the marital property between them and then must be ratified by the marriage registrar, namely the civil registry or the office of religion affairs.

According to Article 29 of Act No. 1 of 1974 concerning Marriage, it does not provide a clear and unequivocal understanding of the marriage agreement, including the contents of the marriage agreement. Only in Article 29 paragraph (2) it is explained about the limits that must not be violated in making a marriage agreement, which reads: The agreement cannot be ratified if it violates the boundaries of law, religion, and decency. ${ }^{13}$

The marriage agreement binds both parties and a third party, which means that the marriage agreement binds the parties as binding the law by referring to the provisions of Article 1338 paragraph (1) of the Civil Code. Agreement when referring to a general agreement as specified in Article 1313 of the Civil Code, that an agreement is an act in which one or more people bind themselves to one or more other people, so that the object of the agreement has no limitations, as long as the object of the agreement is permitted by law. The public order and decency (referring to the provisions of the legal terms of the agreement Article 1320 paragraph (4) of the Civil Code). ${ }^{14}$

In a marriage agreement, the object of the agreement is only

10 Soerjono Soekanto dan Sri Mamuji, Penelitian Hukum Normatif Suatu Tinjauan Singkat, PT. RajaGrafindo Persada, Jakarta, 2007, page.13

11 Masri Singarimbun dan Sofyan Effendi, Metode Penelitian Survei, LP3ES, Jakarta, 1995, page. 10

12 Martias Gelar Imam Radjo Mulono, Penjelasan Istilah-Istilah Hukum Belanda Indonesia, Ghalia, Jakarta, 1982, page.107

13 Annisa Istrianty, Erwan Priambada, Akibat Hukum Perjanjian Perkawinan yang Dibuat Setelah Perkawinan Berlangsung, Privat Law Vol. III No 2 July-December 2015, page.84-92

14 Rahmawati Maliana, Akibat Hukum Perjanjian Kawin Yang Dibuat Setelah Berlangsungnya Perkawinan (Analisis Penetapan Pengadilan Negeri Surabaya Nomor: 543/PDT.P/2015/PN.SBY), JURTAMA Jurnal Kenotariatan Narotama, Vol 1 No 2 August 2019, page.144-157 
limited to property in the marriage. A marriage agreement (huwdijks or huwelijkse voorwaarden) is an agreement made by two prospective husbands and prospective wives before their marriage takes place, to regulate the consequences of marriage involving assets. This marriage agreement is more of a family law, so not all of the legal provisions of the agreement contained in Book III of the Civil Code apply. ${ }^{15}$

Thus, the benefit of those who make a marriage agreement is that the parties will obey the restrictions made by them, namely husband and wife, while this aims to prevent, limit or even reduce the occurrence of conflicts that may occur, especially in the institution of marriage. The agreement on marriage is used as a guideline that regulates the emergence of a dispute between the parties, especially in matters related to property problems in the family. Conflict in the family is never desired, but a marriage agreement will provide legal certainty if a conflict arises and is forced to end in a divorce. For this reason, an act of making a marriage agreement can make a reference to determine the rights and obligations of each husband and wife.

The making of a marriage agreement before the occurrence of marriage in which the agreement must be made before a Notary, with the consequence that if it is not carried out before a Notary, the agreement is canceled, this is in accordance with the meaning of Article 147 of the Civil Code. Marriage agreements bring legal certainty regarding the rights and obligations between husband and wife for the wealth they have, with the provisions of the marriage agreement having broad implications. With the decision of the Constitutional Court No. 69/PUU-XIII/2015 means to be relaxed from the basic meaning contained in the marriage agreement. With the issuance of the Constitutional Court's decision, the marriage agreement should no longer be interpreted as an agreement that can only be held in the absence of a marriage (prenuptial agreement) but an agreement can be made after the marriage occurs. The Constitutional Court granted only part of the petition for reconsideration of the party who submitted the judicial review of Ike Farida, namely an Indonesian citizen who had married a Japanese foreigner. The Constitutional Court gave a constitutional interpretation of Article 29 paragraphs (1), (3), and (4) of Act No. 1/1974.

The core meanings contained in the Constitutional Court's Amar Decision include: 1) A marriage agreement may be made at the time or at the time of the marriage, can be made even before the marriage takes place, and can be made at the time the marriage occurs; 2) In accordance with the agreement stated in the marriage agreement, a marriage agreement can be valid since the marriage is held; 3) Changes to the marriage agreement may be made at the time of the marriage, but must be with the agreement of husband and wife with a note that it is not allowed if it can harm the other party.

The decision of the Constitutional Court on the marriage agreement

15 Soetojo Prawirohamidjojo dan Marthalena Pohan, Hukum Orang Dan Keluarga (Familie Recht), Airlangga University Press, Surabaya, 2001, page.74 
is a double-edged sword. On the one hand, the marriage agreement can save Indonesian citizens who marry with foreigners from losing their rights to have certificates of land rights, especially Property Rights (HM) and Building Use Rights (HGB). But on the other hand it has a negative impact if the parties to the marriage agreement are motivated by bad faith, for example people make a marriage agreement with the aim of eliminating the rights of the heirs, for example in the case of a father making a marriage agreement with his wife who is dying and is expected to die. In the end, it was discovered that there was a conflict between the father and his children so that a legal loophole was used to make a marriage agreement with the intention that when the mother died, the inheritance to her child was not open. The marriage agreement is made with the intention of sacrificing interests and losses to the inheritance rights of their children. In this example, the marriage agreement made after the marriage contains elements of an unlawful act.

Constitutional Court Decision No. 69/PUU-XIII/2015 has changed the new paradigm of the content of a law that has been tested and the change causes the norm of a regulation or law to change to a new provision, namely the making of a marriage agreement from before it was done now can be done after the existence of a marriage agreement. The Constitutional Court has made legal reforms with the issuance of the Constitutional Court's decision Number 69/PUU/XIII/2015. With the decision of the Constitutional Court, the deadline for holding a marriage agreement is wider, not only before or when the marriage takes place but can also be held after the marriage takes place. In the end, couples who want to get married no longer need to think about a marriage agreement because now it can be held after the marriage takes place. Then each couple will focus more on the main purpose of marriage, which is to be able to form a sakinah, mawaddah, and rahmah family, without thinking about worrying about marital property later. If later in the middle of the journey in navigating household life there are problems regarding marital property or others, a marriage agreement can be immediately concluded with the consent of the parties, but this is only the worst possibility in a marriage. The hope is that all married couples can live happily, with love, live in peace with their partners. ${ }^{16}$

Legal Considerations in Decision No. 69/PUU-XIII/2015 compiled by the MKRI turned out to have 3 crucial problems. First, the consideration regarding the examination of the UUPA contains a logical error of thinking (fallacy) because it equates different things, namely the marital status of Indonesian citizens and the classification of who can become Indonesian citizens. Second, the Constitutional Court does not give much consideration to matters that are decided and formulated in its Petitum, particularly in relation to the interpretation of Article 29 paragraph (1), Article 29 paragraph (3) and Article 29 paragraph (4) of the Marriage

16 Moh. Faizur Rohman, Implikasi Putusan Mahkamah Konstitusi Nomor 69/PUU/XIII/2015 Tentang Perjanjian Perkawinan Terhadap Tujuan Perkawinan, Al-Daulah: Jurnal Hukum dan Perundangan Islam, Vol 7, No 1, April 2017, page.1-27 
Law. Third, the Constitutional Court did not consider the impact of changes in the characteristics of the marriage agreement. ${ }^{17}$

Constitutional Court Decision No. 69/PUU-XIII/2015, has led to changes in legal norms that are legally recognized in accordance with constitutional law in Indonesia, the Constitutional Court's decision has been accepted as a new legal norm in the hierarchy of marriage law in Indonesia. However, whether the new norm provides legal protection or vice versa is the emergence of legal uncertainty until now remains a pro and contra because it is open to the possibility of unlawful acts with abuse in the making of the marriage agreement deed which is carried out when the marriage has occurred which is detrimental to third parties. .

Husband and wife who make a marriage agreement at the time of marriage according to reasons that can be accepted as fairness and good faith, for example: First, to avoid losing ownership of land with HM and HGB certificates. Second, the making of a marriage agreement after marriage for reasons of eliminating the partnership of joint assets of husband and wife in order to make it easier to sell assets, make it easier to pledge assets, make it easier to give grants between husband and wife, on the other hand there are also people who make marriage agreements after marriage in bad faith and are categorized an act against the law because it harms the interests of a third party, for example in the following cases: First, the making of a marriage agreement after marriage for reasons of eliminating responsibility to a third party, where the debtor owes a debt and avoids the occurrence of confiscation of collateral (conservatoir beslag). Second, eliminating tax responsibilities, in the field of taxation, the marriage agreement is used to separate the assets of husband and wife so that when a tax audit is carried out, some assets are not included in the assets being examined so that it can harm the state. Third, eliminating the inheritance rights of the heirs.

In the Civil Code, unlawful acts are regulated in accordance with article 1365 of the Criminal Code or Burgerlijk Wetboek (BW). In accordance with the article, there are elements of unlawful acts, namely the existence of an unlawful act, the presence of an error, the cause and effect between the loss and the act accompanied by the loss.

In general, there are 3 (three) categories of unlawful acts as follows: 1. unlawful acts due to intentional, 2. unlawful acts without intentional or negligence, 3. unlawful acts due to negligence. As for being categorized as an unlawful act, it is an act that does not match the rights of another person (inbreuk op eens anders recht) in this case one of the actions prohibited by Article 1365 of the Civil Code. The rights that are violated are the rights of a person who is recognized by law, including but not limited to the following rights: a) Privately owned rights, b) Property rights, c) Existing rights as freedoms, d) Rights to honor and

17 Damian Agata Yuvens, Analisis Kritis terhadap Perjanjian Perkawinan dalam Putusan Mahkamah Konstitusi Nomor 69/PUU-XIII/2015, Jurnal Konstitusi, Vol 14, Nomor 4, December 2017, page.799-819 
good name. The elements of acts against civil law include the existence of unlawful acts, the existence of errors, the cause and effect between the loss and the act and the loss. ${ }^{18}$

As a state of law, the decision of the Constitutional Court is a part that must be obeyed by every citizen, including the state. The decision of the Constitutional Court has determined and ordered that the existing decisions of the Constitutional Court must be published in a state Gazette of the Republic of Indonesia. The legal action is aimed at fulfilling the principles of publicity and law enforcement. Law enforcement for Ike Farida as the applicant for the examination of Article 29 paragraphs (1), (3), and (4) of Act No. 1/1974 on the 1945 Constitution brought about an unequal point of view, namely the difference between the interests of the state/government, the applicant for the judicial review, and the point of view of the panel of judges. But what is called a legal decision that has been hammered out must of course be obeyed by the parties, including the wider community and the government. The Constitutional Court's decision not only has implications for the pros and cons in the community but also raises pros and cons during its implementation, namely to the public official who is tasked with making a marriage agreement deed, namely a notary. For this reason, notaries are only required to be careful when making a marriage agreement in the event that the marriage has already taken place, while in terms of risk, it must be borne alone.

The main objective of the Constitutional Court's decision no. 69/PUU-XIII/2015 is to resolve the mixed marriage problem in the Ike Farida case where a marriage between an Indonesian citizen and a foreigner loses the right to own land with HM or HGB. However, it is very unfortunate that this decision creates new problems for notaries. Notaries who are given full authority in making the marriage agreement deed either when the marriage begins or during the marriage bond takes place. The elimination of procedures through the courts or courts makes the process of notary accountability even more burdensome for the contents of the deed made.

Based on the decision of the Constitutional Court, it is obligatory that the marriage agreement must be made before a notary so that the marriage agreement deed has perfect power in the eyes of the law and is binding on the parties or other third parties. However, at the implementation level, there are obstacles, including: First, although the marriage agreement made by a notary has fulfilled the formal requirements for making a deed of ownership of the property of both parties, it is still not final because it still depends on the approval of other institutions, namely the civil registration institution and the KUA. This causes legal uncertainty, notaries seem to be subordinate to other state institutions. Second, the Notary is given the burden to be careful but there are no clear rules of the game, so there is no basis to protect the Notary in the preparation of the draft agreement. As a result, it will be

18 Indah Sari, Perbuatan Melawan Hukum (PMH) Dalam Hukum Pidana Dan Hukum Perdata, Jurnal IImiah Hukum Dirgantara, Vol 11 No. 1, September 2020, page.53-70 
vulnerable to smuggling of laws related to losses to third parties.

The Notary really appreciates the steps taken by the Constitutional Court, with this decision. Now the community or every Indonesian citizen has the same right to own a house and land, especially for married couples who are involved in mixed marriages. Likewise, married couples who have not entered into a marriage agreement at the time of marriage. However, based on the implementation, many problems were encountered, especially in the notary who was given the mandate after the decision of the Constitutional Court was issued.

The convenience provided by the Constitutional Court, especially for those who will make a marriage agreement deed, turned out to cause polemics for and against, finally many notaries still doubted the making of a marriage agreement deed after marriage. This is because the decision automatically binds two elements of the official. Professional officials who are not at all the domain of the executive, judiciary, or legislative. Likewise, the domain of public officials, namely the executive. Both parts must make adjustments to the decisions of a judicial institution and this becomes a new problem, namely the legal certainty of the parties in making the marriage agreement and the risk that arises for the notary who makes the agreement.

The principal and notary authority based on UUJN is to make or produce an authentic deed, ${ }^{19}$ Notaries are given the authority to make a marriage agreement deed after the Constitutional Court's decision. Notaries are not part of government institutions or as civil servants, for this reason, a new regulation is not needed for the enactment of the Constitutional Court's decision. This means that the notary can directly implement the decision without having to wait for the new regulation to implement the decision. This also has implications for the burden of the notary. There are differences in the interpretation of each notary of the Constitutional Court's decision.

The decision of the Constitutional Court Number 69/PUU/XII/2015 adds the authority for a Notary to ratify a marriage agreement, so that a marriage agreement is not only made by a marriage registrar but can also be ratified by a Notary. The decision of the Constitutional Court Number 69/PUU/XII/2015 has permanent and binding legal force since it was pronounced before a court open to the public (final and binding). The decision of the Constitutional Court Number 69/PUU/XII/2015 which granted the Petitioner's petition has the legal effect of Article 29 paragraphs (1), (3) and (4) of the Marriage Law being conditionally unconstitutional. The decision of the Constitutional Court Number 69/PUU/XII/2015 creates a new legal situation (declaratoir constitutif) which in this case the Constitutional Court is a negative legislator, so that the Constitutional Court's Decision Number 69/PUU/XII/2015 is the same as a constitutional order. The decision of the Constitutional Court Number

19 Elvira Fitriyani Pakpahan, Vivi Prisilla, Dicky, Yuni Adriana Malau, Peran dan Kewenangan Profesi Penunjang Pasar Modal (Notaris) Dalam Menghadapi Era Globalisasi, JCH (Jurnal Cendekia Hukum), Vol 5 No 2, March 2020, page.323-332 
69/PUU/XII/2015 has binding legal force, not only binding on the litigants (interpartes), but also binding and/or intended for all citizens, state institutions/officials and legal entities within the territory of the Republic of Indonesia (erga omnes). Based on this, the Decision of the Constitutional Court Number 69/PUU/XII/2015 is binding on the Notary, the Population and Civil Registration Office or the Office of Religious Affairs (KUA) as the official authorized to ratify the marriage agreement. $^{20}$

As a reference that is guided by the Notary to provide an interpretation of the Constitutional Court's decision by upholding morals and obeying the professional ethics of the notary. If each notary also has different guidelines as a basis for making decisions as long as it does not conflict with norms and does not harm other third parties. In addition, there is an additional requirement for the obligation to obtain legalization by the Population and Civil Registry Office (DISKUCAPIL) or the Office of Religious Affairs (KUA) which should be an institution of choice and additional to carry out records for government administrative requirements. As for the issuance of the Director General of Dukcapil Letter No: 472.2/5876/Dukcapil on 19/05-2017 regarding the need for recording and reporting a marriage agreement as well as a letter from the Director General of Islamic Binmas No: B.2674/DJ.III/KW.00/9/2017 dated 28/09-2017 regarding the recording of marriage agreements can be an ambiguous or different interpretation. The marriage agreement deed can be interpreted as not being able to bind the parties who made it or bind third parties, in other words there is no binding legal force if it has not been legalized by DISKUCAPIL for non-Muslims and KUA for Muslims.

One of the prominent problems with regard to the Notary Deed in terms of making a marriage agreement with the Notary Deed, is the provision that no changes may be made as regulated in Article 149 of the Criminal Code. Civil law, that "After the marriage takes place, the marriage agreement in any way, may not be changed." In the Compilation of Islamic Law, it is stipulated in Article 50 paragraph (2) that, "A marriage agreement regarding property can be revoked with the mutual consent of husband and wife and must register it at the Marriage Registrar's Office where the marriage takes place." Meanwhile, Act No. 1 of 1974 concerning Marriage stipulates in Article 29 paragraph (4) that 'As long as the marriage lasts, the agreement cannot be changed, unless from both parties there is an agreement to change and the change does not harm a third party. ${ }^{\prime \prime 21}$

Notaries criticize that in fact, clearer implementing rules are needed for making marriage agreements after marriage. The marriage

20 Firman Floranta Adonara, Kewenangan Notaris Mengesahkan Perjanjian Kawin Sebagai Amanat Konstitusi, Jurnal I/mu Kenotariatan, Vol 1 Issue 2 (2020), page. 55-73

21 Qadryan R. Sumaryono, Kewenangan Notaris Dalam Membuat Akta Perjanjian Perkawinan Menurut UU NO. 2 Tahun 2014 Jo. UU No. 30 Tahun 2004 Tentang Jabatan Notaris, Lex Privatum Vol. V/No. 9/Nov/2017, page.74-82 
agreement must be determined in the form and type that is allowed and what is prohibited. The authority of DISKUCAPIL and KUA is in the register portion as proof of administrative order and not to determine the authenticity of the marriage agreement deed. Because the authority to legalize is attached to the notary as a public official.

The enforcement of the Constitutional Court's decision No.69/PUUXIII/2015 must be supported by clearer and more detailed implementing regulations. The function of the state is to enforce justice and protect the rights of its citizens. The government is allowed to participate in matters concerning the rights of a person in order to ensure the economic distribution of all people equally. With clearer arrangements regarding marriage agreements made after the marriage takes place, the law is a tool for reform and change in society. The state through its agencies and instruments must be able to read changes and developments that occur in society, additional rules are needed or limit rules that can hinder developments that occur in the modern world, namely social and global economy.

Constructive law creates goodness for all stakeholders, including notaries as public officials as authentic deed makers. Notaries have clear rules and references so that they can apply the precautionary principle in making a marriage agreement after a marriage takes place. If the written agreement is ratified by the competent authority, in this case the marriage registrar, it is feared to what extent the ability and skill of the Marriage Registrar is to be able to examine that a marriage agreement is contrary to or in accordance with legal, religious and moral boundaries. ${ }^{22}$

If the draft is in accordance with legal, religious and moral limitations, the Court will approve or ratify it and conversely the court will refuse to approve or refuse to ratify it if it is not in accordance with legal, religious and moral boundaries. The legal limits include the interests of creditors that must be protected or not harm creditors with good intentions. Parties who are dissatisfied because of the court's refusal to ratify the draft marriage agreement, can appeal, but this means that the prospective husband and wife and/or husband and wife can only marry with joint property.

\section{CONCLUSION}

The Constitutional Court's decision No. 69/PUU-XIII/2015 resulted in the marriage agreement being held before the marriage and after the marriage. The Constitutional Court's decision has changed the principle of Article 147 of the Civil Code which states that a marriage agreement must be carried out using a notary deed before the marriage takes place, Article 29 paragraph (1) of Act No. 1 of 1974 which provides a time limit for making a marriage agreement, which can only be held at or before the marriage is carried out. From the results of the study, it was found that there were no problems with the marriage agreement which was held

22 Hendry Lee A Weng, beberapa Segi Hukum Dalam Perjanjian Perkawinan, Some Legal Aspects Of Marriage Contract, Rainbow, Medan, 1990, page.153 
before or during the marriage. Provided that the marriage agreement does not harm third parties. However, from the various cases found in the study, it is known that the marriage agreement made after the marriage still leaves a gap for people with bad intentions to commit acts against the law and present losses to third parties as contained in Article 1365 of the Civil Code. A notary must be professional, thorough and thorough, when carrying out his position a notary must be guided by the precautionary principle and provide services in accordance with the provisions of the law as contained in article 16 paragraph (1) letter e of Act No. 30 of 2004 concerning the Notary Position.

\section{Books}

\section{BLIBIOGRAPHY}

Abdul Rahman Ghozali, 2014, Fiqh Munakahat, Kencana Prenadamedia Group, Jakarta;

Ali Afandi, 1986, Hukum Waris, Hukum Keluarga, Hukum Pembuktian, Bina Aksara, Jakarta;

Hendry Lee A Weng, 1990, beberapa Segi Hukum Dalam Perjanjian Perkawinan, Some Legal Aspects Of Marriage Contract, Rainbow, Medan;

Martias Gelar Imam Radjo Mulono, 1982, Penjelasan Istilah-Istilah Hukum Belanda Indonesia, Ghalia, Jakarta;

Masri Singarimbun dan Sofyan Effendi, 1995, Metode Penelitian Survei, LP3ES, Jakarta;

Rahmat Hakim, 2000, Hukum Perkawinan Islam (untuk IAIN, STAIN, PTAIS), CV Pustaka Setia, Bandung;

Soerjono Soekanto dan Sri Mamuji, 2007, Penelitian Hukum Normatif Suatu Tinjauan Singkat, PT. RajaGrafindo Persada, Jakarta;

Soetojo Prawirohamidjojo dan Marthalena Pohan, 2001, Hukum Orang Dan Keluarga (Familie Recht), Airlangga University Press, Surabaya;

Sonny Dewi Judiasih, Bambang Daru Nugroho, Deviana Yuanitasari, Revi Inayatillah, 2018, Perjanjian Kawin Setelah Berlakunya Putusan Mahkamah Kostitusi No.69/PUU-III/2015, Cakra, Bandung;

Titik Triwulan, 2011, Hukum Perdata Dalam Sistem Hukum Nasional, Kencana Prenada Media Grup, Jakarta.

\section{Journals}

Bagir Manan, Prasyarat Kemerdekaan Kekuasaan Kehakiman, Varia Peradilan Majalah Hukum Year XXX No.348 Nopember 2014;

Annisa Istrianty, Erwan Priambada, Akibat Hukum Perjanjian Perkawinan yang Dibuat Setelah Perkawinan Berlangsung, Privat Law Vol. III No 2 JulyDecember 2015;

Damian Agata Yuvens, Analisis Kritis terhadap Perjanjian Perkawinan dalam Putusan Mahkamah Konstitusi Nomor 69/PUU-XIII/2015, Jurnal Konstitusi, Vol 14, Nomor 4, December 2017; 
Elvira Fitriyani Pakpahan, Vivi Prisilla, Dicky, Yuni Adriana Malau, Peran dan Kewenangan Profesi Penunjang Pasar Modal (Notaris) Dalam Menghadapi Era Globalisasi, JCH (Jurnal Cendekia Hukum), Vol 5 No 2, March 2020;

Eva Dwinopianti Implikasi dan Akibat Hukum Putusan Mahkamah Konstitusi Nomor 69/Puu-Xiii/2015 terhadap Pembuatan Akta Perjanjian Perkawinan Setelah Kawin yang Dibuat di Hadapan Notaris, Lex Renaissance, Vol. 2 No. 1 January 2017;

Evi Djuniarti, Hukum Harta Bersama Ditinjau Dari Perspektif Undang-Undang Perkawinan dan KUHPerdata, Jurnal Penelitian Hukum De Jure, Vol. 17 No. 4 December 2017;

Firman Floranta Adonara, Kewenangan Notaris Mengesahkan Perjanjian Kawin Sebagai Amanat Konstitusi, Jurnal Ilmu Kenotariatan, Vol 1 Issue 2 (2020);

I Nyoman Putu Budiartha, Dilema Penegakan Hukum Putusan MK No.69/PUU-XII/2015 (Persoalan Perkawinan Campuran Tanpa Perjanjian Kawin), Jurnal Notariil, Vol. 1, No. 2, May 2017;

Indah Sari, Perbuatan Melawan Hukum (PMH) Dalam Hukum Pidana Dan Hukum Perdata, Jurnal IImiah Hukum Dirgantara, Vol 11 No. 1, September 2020;

Moh. Faizur Rohman, Implikasi Putusan Mahkamah Konstitusi Nomor 69/PUU/XIII/2015 Tentang Perjanjian Perkawinan Terhadap Tujuan Perkawinan, Al-Daulah: Jurnal Hukum dan Perundangan Islam, Vol 7, No 1, April 2017;

Qadryan R. Sumaryono, Kewenangan Notaris Dalam Membuat Akta Perjanjian Perkawinan Menurut UU NO. 2 Tahun 2014 Jo. UU No. 30 Tahun 2004 Tentang Jabatan Notaris, Lex Privatum Vol. V/No. 9/Nov/2017;

Rahmawati Maliana, Akibat Hukum Perjanjian Kawin Yang Dibuat Setelah Berlangsungnya Perkawinan (Analisis Penetapan Pengadilan Negeri Surabaya Nomor: 543/PDT.P/2015/PN.SBY), JURTAMA Jurnal Kenotariatan Narotama, Vol 1 No 2 August 2019; 